\title{
THE EFFECT OF EDUCATION AND SPORTING EXPERIENCE OF IRANIAN PREMIER LEAGUE FOOTBALL PLAYERS ON THEIR AWARENESS OF SPORTS LAW
}

\section{O EFEITO DA EDUCAÇÃO E DA EXPERIÊNCIA ESPORTIVA DOS JOGADORES DE FUTEBOL DA PREMIER LEAGUE NA CONSCIENTIZAÇÃO DOS DIREITOS ESPORTIVOS}

\section{EL EFECTO DE LA EDUCACIÓN Y LA EXPERIENCIA DEPORTIVA DE LOS JUGADORES DE FÚTBOL DE LA PREMIER LEAGUE DE IRÁN SOBRE SU CONOCIMIENTO DEL DERECHO DEPORTIVO}

\section{Mahdi Azimi ${ }^{1}$ \\ Seyed Amir Reza Hosseinipour Rafsanjani ${ }^{2}$ \\ Mona Torkaman ${ }^{3}$}

\begin{abstract}
The purpose of this study was to investigate the relationship between education and athletic background of Premier League football players on their awareness of sports Law. In this study, descriptive-analytical method and Spearman correlation coefficient were used. Ninety-five percent level was used as the criterion for rejecting the hypothesis. Questionnaires about variables were used to identify the sample group and the main questions about players' legal awareness were used for data collection. The results showed that Pearson correlation coefficient was 0.107, Spearman correlation coefficient was 0.204 and Kendall correlation coefficient was 0.139 and significant was 0.88 . There is no relationship between awareness of sports law and the history of sports in the Premier League. Pearson correlation coefficient of 0.388, Spearman correlation coefficient of 0.204 and Kendall correlation coefficient of 0.139 and significant value of 0.001 indicated that there is a relationship between sport legal awareness and education of the Iranian Premier League players.
\end{abstract}

Keywords: Premier League players, sports Law, legal awareness, education level, playing history.

Resumo: O objetivo deste estudo foi investigar a relação entre educação e formação atlética de jogadores de futebol da Premier League na conscientização dos direitos esportivos. Neste estudo, foram utilizados o método analítico-descritivo e o coeficiente de correlação de Spearman. O nível

\footnotetext{
${ }^{1}$ Islamic Azad University, Kerman, Iran.

${ }^{2}$ Kish International University, Iran.

${ }^{3}$ Research Sciences University, Iran.
} 
de noventa e cinco por cento foi utilizado como critério para rejeitar a hipótese. Questionários sobre variáveis foram utilizados para identificar o grupo amostral e as principais questões sobre conscientização jurídica dos jogadores foram utilizadas para a coleta de dados. Os resultados mostraram que o coeficiente de correlação de Pearson foi de 0,107 , o coeficiente de correlação de Spearman foi de 0,204 e o coeficiente de correlação de Kendall foi de 0,139 e significativo foi de 0,88 . Não há relação entre a conscientização do direito esportivo e a história do esporte na Premier League. O coeficiente de correlação de Pearson de 0,388, o coeficiente de correlação de Spearman de 0,204 e o coeficiente de correlação de Kendall de 0,139 e valor significativo de 0,001 indicaram que existe uma relação entre a conscientização jurídica do esporte e a educação dos jogadores iranianos da Premier League.

Palavras-chave: jogadores da Premier League, direitos esportivos, conhecimento jurídico, nível de educação, histórico de jogo.

Resumen: El propósito de este estudio fue investigar la relación entre la educación y los antecedentes atléticos de los jugadores de fútbol de la Premier League y su conocimiento del derecho deportivo. En este estudio se utilizó el método descriptivo-analítico y el coeficiente de correlación de Spearman. Se utilizó un nivel del noventa y cinco por ciento como criterio para rechazar la hipótesis. Se utilizaron cuestionarios sobre variables para identificar el grupo de muestra y las principales preguntas sobre la conciencia jurídica de los jugadores para la recopilación de datos. Los resultados mostraron que el coeficiente de correlación de Pearson fue de 0.107, el coeficiente de correlación de Spearman fue de 0.204 y el coeficiente de correlación de Kendall fue de 0.139 y significativo fue de 0.88 . No existe relación entre el conocimiento del derecho deportivo y la historia del deporte en la Premier League. El coeficiente de correlación de Pearson de 0,388, el coeficiente de correlación de Spearman de 0,204 y el coeficiente de correlación de Kendall de 0,139 y el valor significativo de 0,001 indicaron que existe una relación entre la conciencia legal del deporte y la educación de los jugadores de la Premier League iraní.

Palabras clave: Jugadores de la Premier League, derecho deportivo, conciencia legal, nivel educativo, historial de juego.

\section{INTRODUCTION}

Sports law is one of the tendencies of law science in which some of it deals with the legal analysis of events in sport. The term sport has a broad meaning in this term, and the operations and activities of the championship sport are part of this series. In general, it can be said that sporting events are all offenses and quasi-offenses directly or indirectly committed by athletes, teachers, coaches, managers, spectators, makers and producers of equipment and the like. The subject of these events may be health, life, property, dignity, dignity and other legal rights of individuals who are somehow present in the sport. Concerns exist about the lack of adequate information on athletic rights by athletes (Aghaeinia, 2010). 
The ignorance of the entire sporting community about the legal consequences of offenses and offenses in the sporting environment due to the lack of training and the lack of regular collections that include the type of offenses and their penalties has always added to the quantitative and qualitative spread of offenses. Athletes generally believe that their unlawful actions in sports activities and their lack of awareness of their civic responsibilities will ultimately lead to disciplinary punishment, and the decision-making authority is referred to by judicial committees, federations or managers. Coaches, referees, supervisors, athletic directors, whether they are responsible for themselves or for athletes, are usually no more.

The study of sports law teaches the sports community how to participate in sports activities in order to understand the events that result, the legal responsibilities that ultimately lead to punishment, deprivation of social rights and compensation. Nowadays, sports law is taught and taught to athletes, coaches, and referees as a knowledge requirement in most sports colleges and courses, and to raise awareness and understanding of their situation and control. Exercises and movements in sports fields when practicing or competing and even in non-athletic times have found their own character, especially for national heroes, a deterrent and effective factor in adhering to a champion's morality and good behavior that has helped a lot. Even outdoors, as a champion and athlete, watch out for your movements, actions, and behavior. They are veins (Chalabi, 2006).

Sports Laws, by which civil or criminal liability can be defined in sports law, are divided into two groups: 1) A group that has a variety of games. 2) A group that imposes special care and precaution on players whose aim is to ensure the safety and non-violence of sports games. Civil liability law is interested in the second group and is concerned with the study and determination of their value, and it is in this group that sports error and its effect on legal relations arise. Whereas the general rules of liability in sports law may not exist, for some reason The beatings are often controversial in this respect. The players, in the relationship between themselves and the coaches, are bound by an implied contract, the most important of which is the acceptance of the usual sporting risks that occur in enforcing specific rules of the game. Emergency and legitimate defense must also be taken into account in these circumstances. Violation of this standard conduct is a mistake and causes civil liability. The responsibility for the spectators of the sport's damage is primarily borne by the organizers, unless it is due to the players' error or the spectator's actions (Katouzian, 2009).

The issue of sports Law in Iran was enshrined in Article 42 of the General Penal Code in 1973, which stipulated: "Accidents resulting from sporting activities shall not constitute a crime as a result 
of accidents which do not violate the provisions of that sport". In 1361982, the legislature approved the same text by adding a sentence (... and these rules do not contradict the religious rules) in Article 32 of the Islamic Penal Code. In 1991, despite the changes made to the Islamic Penal Code, Article 32 was recently adopted only by amending Article 59 to the present, and is currently being cited for incidents involving sporting operations that have a criminal effect (Aghaeinia, 2010).

In general, it seems that with regard to the social foundations of society, the interests of the community should be more appropriate in order to engage more people in sports activities and to prevent their tendency, especially for the younger generation, to deviate from their values. Finally, it tends to support athletes who, in breach of laws and regulations, have made it easier for others to approach the community in the best way possible, without violating laws or regulations. Despite the importance of the sports Law issue and the need to pay attention to it, very little research has been done in this area.

Ghabeljoo (1998) examined the insurance coverage of football players and concluded that the quality of medical services, delays in payments, tariffs, lack of an institution or committee for the control and evaluation of services provided to individuals can be pointed out.

Foroughipour (2004) evaluated the familiarity of sports coaches, teachers and sport managers with the rights of sport in Tehran and the presentation of its educational strategies.

Binan (2013) examined the extent of teachers' legal awareness and civic responsibility during the school physical education lesson. The method of this study was field-survey research which was conducted in field. For this purpose, 175 physical education teachers were selected by random sampling. Data gathering tool was a researcher-made questionnaire that its reliability was tested by test-retest method and the coefficient of 0.86 was obtained. For data analysis, Kolmogorov-Smirnov test was used for normal distribution of data and non-parametric Mann-Whitney and Kruskal-Wallis statistics were used for data distribution. The findings of the study showed that 81/45 percent of physical education teachers were aware of their legal duties and responsibilities during physical education lessons. There was also a significant difference between women's and men's views on legal responsibilities $(p<0.05)$, meaning that female physical education teachers were more aware of legal responsibilities than men. From the educational point of view, there was a significant difference between physical education teachers with different degrees of awareness of sport rights $(p \geq 0.05)$, meaning that teachers with a master's degree and higher were more aware than others. There was also a significant difference $(p \geq 0.001)$ between teachers' views on service history, 
meaning that teachers with a history of above-average service (15 years or older) were more aristocratic in terms of legal awareness.

Binan and Kashef (2014) explored the differences in the attitudes of female and male sports coaches in sporting events. The research method consisted of field-survey research which was conducted in the field. For this purpose, 175 coaches of sport centers and sports centers were selected using random sampling. The data gathering tool was a researcher-made questionnaire that its reliability was tested by test-retest method and the coefficient of $86 \%$ was obtained. For data analysis, Kolmogorov-Smirnov test was used for normal distribution of data and non-parametric Mann-Whitney and Kruskal-Wallis statistics were used. The findings of the study showed that $81 / 45 \%$ of the coaches were aware of their legal duties and responsibilities in sporting events. There was also a significant difference between women's and men's views on legal responsibilities $(P \leq 0.05)$, meaning that female athletes were more knowledgeable about legal responsibilities than men in terms of educational attainment. There was a significant difference in the difference in knowledge of sports law ( $\mathrm{p} \leq 0.05)$, meaning that coaches with a master's degree and higher knowledge were more knowledgeable than others in the managerial experience. There was a $p$ value of 0.001 (mean of coaches with a median experience of 15 years). They were more aristocratic in their legal consciousness.

Zadehjafari, Nouraei and Pour Ranjbar (2015) examined the level of awareness of sports Law among experts of sports committees and Kerman province Youth and Sports Directorate. This research is a descriptive correlational one which is considered in the field of applied research in terms of purpose. The statistical population of this study consisted of all male and female experts of Kerman province's Sport and Youth Administration and Sport Committees in 2015 with a total of 194 individuals. To determine the sample size, the total number method was used and after distributing the questionnaire 166 questionnaires were returned. Questionnaire (Asgari, 2015) consisting of 40 closed-ended questions (two levels of public awareness and specific awareness of sport rights) was used to collect the required information. The reliability of the questionnaire was calculated as 0.93 using Cronbach's alpha method. Descriptive statistics (mean, standard deviation, frequency of tables) and inferential statistics (one sample t-test, Pearson correlation coefficient and chi-square test) were used for data analysis. The results showed that the level of general and specific awareness of sport rights of sports experts and Kerman youth and sports administration is in accordance with the criterion score (12). Also, there is a significant relationship between the level of awareness of sports Law and experience in sport and education level of the target community. 
Football is one of the most popular sports in Iran and worldwide. Therefore, given the importance and importance of soccer sport in the country and in the world, there is a need for research in the field of sports law and legal awareness in football. Because every year the media watches the incidents that happen in the Premier League matches, which is due to little legal information or lack of legal awareness of players or players that caused problems or controversy. In addressing the issue of lack of legal awareness in football, the responsibility of the athlete, spectator, coach and supervisor and those involved in some form of football competence should be addressed, as raising the level of legal awareness of these individuals by the percentage of accidents. And it reduces their problems in the tournament. Therefore, it is necessary to conduct a comprehensive research on the level of awareness of football players about sports Law.

In this regard, the present study aims to describe and examine the relationship between the awareness of the sporting rights of Premier League players with their athletic background, and the relationship between the awareness of the sporting rights of Premier League players with their education level.

\section{RESEARCH QUESTION}

For the purpose of this review, and in order to achieve it, the following questions have been posed:

1. Is there any significant relationship between the level of awareness of players' sports Law and their athletic background (playing experience)?

2. Is there a significant relationship between the level of awareness of players' sports Law and their level of education?

\section{METHODOLOGY}

The research method was survey research in which library study, Delphi technique and questionnaire were used to collect the required information. The statistical population includes the first division soccer players of the country in 2012. These include 324 people. The figures are based on statistics from the AFC. In this research, as community members are distributed within teams, random sampling is used. This means that the information and opinions of the soccer players of the 
top ten national teams (180 people) were collected. This sample size is obtained by the method of sample size determination by maximum error method.

Sports Law Awareness Questionnaire: A questionnaire was used to measure the players' knowledge of their sport rights. This questionnaire measures the level of legal awareness of players in sports law in three areas: contracts, disciplinary regulations, and basic issues of sports law. The validity of the questionnaire is known to the player with a knowledge of sports law of 0.94 .

For collecting data, 190 questionnaires were distributed among the first league football players and finally after 2 months, 180 questionnaires were collected. Data analysis was performed at two levels of descriptive and inferential statistics. In the descriptive section, the research data were described using mean, median, fashion, frequency, percentage of frequency. In order to correlate between variables, inferential statistical tests such as regression, Kendall, Spearman, and distribution graphs were used. All statistical analyzes were performed by SPSS software.

\section{RESULTS}

Descriptive findings related to demographic characteristics of the sample indicated that among 76 players studied, 71 indicated age of their sport, 3 of them were 4 (\%) less than 5 years, 22 (31 (5\%) 10 years and 27 people (38\% 11 to 15 years old and 17 people (24\% 16-20 years old and 2 people $3(\%)$ ) older than 20 years. With regard to education level, 72 people were educated It was noted that $7(10 \%)$ of diplomas, 51 (71\% of diplomas, 1 of $1(1 \%)$ postgraduates, $13(18 \%)$ of bachelors).

Descriptive statistics on the level of legal awareness of sports law among the Premier League players by examining the varied legal awareness and its three dimensions (basic issues and principles of sports law, discipline provisions, contract discussions and players' consent) The mean awareness was $121.86 \%$, with a standard deviation of 22.97 . Inferential statistics section was used to investigate the research questions. Correlation coefficient tests were used to investigate the research questions and hypotheses.

\section{Findings related to the first question and hypothesis}

Correlation tests of the first question whether there is a relationship between legal awareness and players' athletic background? Correlation test was used to test this hypothesis based on players' opinions. In this test, the assumption of zero and the opposite assumption are as follows: 
Assumption of zero: There is no relationship between awareness of sports Law and athletic background of Premier League players. The correlation coefficient between the two variables of awareness of sports law and sporting history of Premier League players is zero. The assumption against this was that there was a relationship between awareness of sports law and the history of sports in the Premier League. (The correlation coefficient between the two variables of awareness of sport rights with the sport history of the premier league players is zero.

Table 1- Correlation coefficient to examine the relationship between players' athletic background and awareness of sports Law

\begin{tabular}{|c|c|}
\hline Pearson correlation coefficient & 0.107 \\
\hline $\begin{array}{c}\text { Spearman correlation } \\
\text { coefficient }\end{array}$ & 0.204 \\
\hline Kendall correlation coefficient & 0.139 \\
\hline Number & 76 \\
\hline P value & 0.088 \\
\hline
\end{tabular}

Relationship between players' athletic experience and awareness of sports Law showed that out of 76 players, Pearson correlation coefficient was 0.107 , Spearman correlation coefficient was 0.204 and Kendall correlation coefficient was 0.139 and $p$ - value was 0.088 . Therefore, the null hypothesis is not rejected at the 0.05 level. There is no relationship between awareness of sports Law and athletic background in the Premier League. (The correlation coefficient between the two variables of awareness of sport rights with the sport history of the Premier League players is zero.) The positive correlation coefficient indicates a direct relationship between the two variables of awareness of sport rights with sport history. This means that as the amount of the variable of athletic history increases, so does the level of awareness of athletic rights. The following distribution charts also confirm this. Kruskal-Wallis test was used for further investigation.

Table 2- Statistics of players with legal awareness

\begin{tabular}{|c|c|}
\hline Statistics & 5.696 \\
\hline Number & 76 \\
\hline p-value & 0.223 \\
\hline Sig. & 0.05 \\
\hline
\end{tabular}

Based on the results of 76 players, the test statistic value is 5.696 and the $p$ value is 0.233 , so the null hypothesis is rejected at the 0.05 level. There is no relationship between awareness of sports Law and athletic background in the Iranian Premier League. (The variable distribution of sport 
rights awareness is similar for players at different levels of their sporting background. As noted, as sporting history increases, so does legal awareness.

\subsection{Findings related to the second question and hypothesis}

Correlation tests for the second question on whether there is a relationship between legal awareness and the level of education of the players. Correlation test was used to test this hypothesis based on players' opinions. In this test, the assumption of zero and the opposite assumption are as follows: Assumption zero: There is no relationship between awareness of sports Law and education level of the Premier League players. The correlation coefficient between the two variables of sport legal awareness and education of Premier League players is zero.

Table 3- Correlation coefficients to examine the relationship between players' education level and awareness of sports Law

\begin{tabular}{|c|c|}
\hline Pearson correlation coefficient & 0.388 \\
\hline Spearman correlation coefficient & 0.399 \\
\hline Kendall correlation coefficient & 0.325 \\
\hline Number & 76 \\
\hline p-value & 0.001 \\
\hline Sig. & 0.05 \\
\hline
\end{tabular}

According to the results of 76 players, Pearson correlation coefficient 0.388 , Spearman correlation coefficient 0.204 , Kendall correlation coefficient 0.139 and significant value 0.001 , thus assuming zero at 0.05 level. That is, there is a relationship between awareness of sports Law and the education of the players in the Premier League. (The correlation coefficient between the two variables of awareness of sport rights with the education of the players in the Iranian Premier League is zero. The positive correlation coefficient indicates a direct relationship between the two variables of awareness of sport rights with education. Increasing awareness of sports Law also increased, and the Kruskal-Wallis test was used to further investigate.

Table 4- Table of statistics of players' education level with awareness of sports Law

\begin{tabular}{|c|c|}
\hline Statistics & 11.762 \\
\hline Number & 76 \\
\hline p-value & 0.008 \\
\hline Sig. & 0.05 \\
\hline
\end{tabular}


Based on the results obtained from 76 players, the test statistic value is 11.762 and the pvalue is 0.088 , so the null hypothesis is rejected at the 0.05 level. There is a relationship between awareness of sports Law and the education of Premier League players.

\section{CONCLUSION}

Based on a general conclusion, the results of this study can be summarized as follows from the research hypotheses. Is there a relationship between awareness of sports Law and players' athletic background? According to the results of 180 players, Pearson correlation coefficient 0.107, Spearman correlation coefficient 0.204 , Kendall correlation coefficient 0.139 and significant value 0.88 , so the null hypothesis is not rejected at 0.05 . There is no relationship between awareness of sports law and the history of sports in the Premier League. The correlation coefficient between the two variables of sport legal awareness and sporting history of the Premier League players was zero. The results of the first hypothesis of the study are consistent with the findings of Binan and Kashef (2013) that there was a significant difference between the views of teachers and those who had a moderate to high level of experience (15 years or more).

In the second question, whether there is a relationship between awareness of sports Law and the education of the players, based on the results of 180 players Pearson correlation coefficient 0.388, Spearman correlation coefficient 0.204 and Kendall correlation coefficient 0.139 and significance level 0.001 . So the null hypothesis is rejected at the 0.05 level. There is a relationship between awareness of sports law and the education of Premier League players. The correlation coefficient between the two variables of sport legal awareness and education of Premier League players is zero. The results of this questioning are in line with those of Binan and Kashef (2013), which showed that teachers with a master's degree and higher were more aware of others. The results are in line with the research of Zadeh Jafari et al. (2015), which showed that there is a meaningful relationship between the level of awareness of sports Law and experience in the field of sport and the level of education of the target community.

In examining the factors associated with players' legal awareness, given the impact of education on this variable, more educated players justify inexperienced players and pass on legal information to them. Therefore, training and justification courses in the field of sports law can be 
effective. Given the importance of the players' legal awareness to other researchers, it is recommended that other sports such as wrestling, volleyball and basketball be researched.

\section{REFERENCES}

AGHAEINIA, H. Sports Law, Sports and Its Legal Responsibilities, Quantity Publications, 2010.

BEHESHTI, Ahmad. The Basics of Physical Education in Islam, Mizan Publisher, 2005.

BINAN, A., \& KASHEF, M. The difference between legal awareness and civic responsibility of male and female sports coaches in sporting events. Applied Research in Sport Management V. 2, N.4 (8 consecutive), 2014, pp. 90-90.

BINAN, ABBAS. the amount of legal awareness and civic responsibility of teachers in physical education classroom. Physical Education Training, 2013, V.2, N.2, pp. 1-10.

CHALABI, R. An Introduction to Sports Law and General Rules of Penal Law, Bamdad Ketab Publishing, 2006.

Dashti, E. Examining the relationship between unwillingness to translate and personality type of Iranian translation students. Journal of Research and Knowledge Spreading, v. 1, n. 1, p. 1-10, 2020.

FOROUGHIPOUR, R. Knowledge of coaches, teachers and sports managers about sports Law, 2014, thesis University Of Tehran, Iran.

Heckler, V. et al. Investigation with experimental practical activities in training geographically distant teachers. Journal of Research and Knowledge Spreading, v, 1, n. 1, p. 1-15, 2020.

KATOUZIAN, N. Introduction to Law Science, Publishing Co, Tehran, Sixty-nine, 2009.

ZADEH JAFARI, N., NOURAEI, T. AND PURANJEBAR, M.S. A Survey on the Knowledge of Sport Rights among the Experts of Sport Committees and Kerman Youth and Sport Directorate General. National Conference on Achievements in Sport Science and Health, 2015, V. 1, pp. 48-55.

\section{$\underline{\text { ABOUT THE AUTORS }}$}

\section{Mahdi Azimi}

PhD Student of Sport Management, Kerman Branch, Islamic Azad University, Kerman, Iran.

Corresponding Author: Email: mehdiazimi99@yahoo.com

ORCID: https://orcid.org/0000-0001-8915-1312 


\section{Seyed Amir Reza Hosseinipour Rafsanjani}

PhD Student in International Law, Kish International University, Iran.

Email: Amir.reza6817@gmail.com

ORCID: https://orcid.org/0000-0002-1448-8591

\section{Mona Torkaman}

PhD Student in Business Management, Qeshm Branch, Research Sciences University, Iran.

Email: Torkaman.6@gmail.com

ORCID: https://orcid.org/0000-0003-1960-937X

Recebido em: 09-15-2020

Aprovado em: 11-25-2020

Publicado em: 12-02-2020 